\title{
Bebeği Yenidoğan Yoğun Bakım Ünitesinde Tedavi Altında Olan Annelerin Yaşadıkları Psikososyal Sorunlar ve Başa Çıkma Yöntemlerinin Belirlenmesi: Niteliksel Bir Araştırma*
}

\author{
Arife TURHAL 國, Aysel KARACA [ $^{2}$
}

\section{ÖZ}

Amaç: Bebeği yenidoğan yoğun bakım ünitesine kabul edilen annelerin stres düzeylerinin arttığı düşünülmektedir. Bu çalışmayla bebeği yenidoğan yoğun bakım ünitesinde tedavi altında olan annelerin yaşadıkları psikososyal sorunlar ve başa çıkma yöntemlerinin belirlenmesi amaçlanmıştır.

Gereç ve Yöntemler: Araştırma, niteliksel yöntemin kullanıldığı tanımlayıcı bir çalışmadır. Bir üniversite hastanesi Yenidoğan Yoğun Bakım Ünitesi'nde bebeği tedavi altında olan 25 anne çalışma grubunu oluşturmuştur. Araştırmanın verileri "Kişisel Bilgi Formu" ve yarı yapılandırılmıș "Niteliksel Görüşme Formu" aracılı̆̆g ile oluşturulmuştur. Görüş̧meler araştırmacı tarafından yüz yüze görüşme yöntemi ile yapılmıştır. Verilerin analizinde tematik analiz yöntemi kullanılmıştır.

Bulgular: Çalışmaya katılan annelerin yaş ortalaması 29.24 'tür ve \%44'ü lise mezunudur. Yenidoğan yoğun bakım ünitesine yatma nedenleri preterm doğum, hiperbilirunemi, konjenital hastalıklardır. Araştırmada altı ana tema ortaya çıkmıştır. Bu ana temalar; 1. Yoğun bakımda bebeğini bırakmış anne olmak (Alt temaları: boş kucak, camın arkasındaki annelik, acının tadı), 2. Endişe denizi (Alt temalar: Ya...olursa, suçlu ben miyim?, tanımlanamayan duygular), 3. Baş etme stratejileri, 4. Beklentiler, 5. Aile hayatındaki değişimler ve 6. Destek sistemleri olarak sınıflandırılmıştır.

Sonuç: Yenidoğan yoğun bakım ünitesinde bebeği yatan anneler yoğun üzüntü, suçluluk ve kaygı yaşamaktadır. Anneler yaşadıkları bu duygular ile başa çıkmakta zorlanmaktadır. Aynı zamanda anneler bu süreçte aile hayatında değişimlerden olumsuz etkilenmektedir. Annelerin yoğun bakım ünite hemşirelerinden ve kendi ailelerinden destek beklentileri vardır.

Anahtar Kelimeler: Niteleyici araştırma; yenidoğan yoğun bakım üniteleri; anneler; psikososyal faktörler; başa çıkma yöntemleri.

\section{Determination of Experienced Psychosocial Problems and Coping Methods of Mothers Whose Infants Are under Treatment in Newborn Intensive Care Unit of Baby: A Qualitative Study}

\begin{abstract}
Aim: Mothers of infants admitted to a neonatal intensive care unit (NICU) are believed to have heightened distress. The aim of this study is determined to the psychosocial problems and the ways of coping mothers whose infants are under treatment in the newborn intensive care unit.

Material and Methods: This is a descriptive study in which a qualitative method is used. 25 mothers whose infants are under treatment in the newborn intensive care unit at university hospital formed the working group. The data of the research was formed through "Personal Information Form", semistructured "Qualitative Interview Form". Interviews had performed using face to face interview method by researcher. Thematic analysis method was used to evaluate the data.

Results: The average age of the mothers in the study is $29.24,44 \%$ had graduated from high school. The admission diagnosis to the NICU was preterm infant, hyperbilirunemia and congenital diseases. Six main themes emerged in the research. These main themes are classed as; 1.To be a mother who left her baby in intensive care (Sub-themes: empty lap, maternity behind glass, taste of pain), 2.Sea of worry (sub-themes: What if, am I a criminal, unidentifying feelings) 3.Coping strategies, 4.Expectations, 5.Changes in family life, 6.Support systems.
\end{abstract}

1 Düzce Üniversitesi, Sağlık Bilimleri Enstitüsü, Hemşirelik E.A.D., Düzce, Türkiye

2 Düzce Üniversitesi, Sağlık Bilimleri Fakültesi, Hemşirelik Bölümü, Düzce, Türkiye

*Bu çalışma 20-23 Kasım 2018 tarihleri arasında Antalya'da düzenlenen V. Uluslararası IX. Ulusal Psikiyatri Hemşireliği Kongresinde sözlü bildiri olarak sunulmuştur. 
Conclusions: Mothers whose infants are in the newborn intensive care unit are experiencing intense sadness, guilt and anxiety. They are having trouble coping with these emotions. At the same time, mothers are negatively affected by changes in family life in this process. Mothers have support expectations from intensive care unit nurses and from their families.

Keywords: Qualitative research; neonatal intensive care units; mothers; psychosocial factors; coping skills.

\section{GiRiș}

Doğum esnasında yaşanan stresli dönemin ardından lohusalık dönemi, annenin bedensel ve fizyolojik değişikliklerin yanında bebeğin sorumlulukları ve bakım ihtiyacının gerektiği özel bir dönemdir. Doğum sonrası değişen hormon düzeyindeki değişikliklere ilaveten bebeğin bakım ve beslenme ihtiyaçlarının sıklığı, ailenin diğer fertleriyle ilgili sorumluluklarının yerine getirilme kaygısı, bozulmuş uyku düzeni, dikkat eksikliği, konsantrasyon güçlüğü ve kendine güven kaybı annenin fiziksel gücünü azaltan en büyük etmenlerdir $(1,2)$. Ayrıca annelerde fiziksel yorgunluğunun yanında, bebeği ile birlikte yeni aile düzeni oluşturmaya çalıştığı yorucu bir dönemdir. Annenin bu dönemdeki ruhsal sorunlar ile mücadele edebilmesi için mental olarak anneliğe hazır olması, fiziksel yorgunluğunu azaltmak için ise bebek bakımında aile içi destekte bulunulması büyük öneme sahiptir (1). Annenin fiziksel ve ruhsal destek ihtiyacının arttığı bu dönemlerde, bebeğinin hastalanması ve hastaneye yatırılarak tedavi planlanması başta anne olmak üzere bütün aile fertlerinde duygusal sorunlar yaşanmasına yol açabilmektedir (3). Doğum sonrası erken dönemde yenidoğanın hastaneye yatırılarak tedavi edilmesi, aileyi bebekleri ile hayal etmedikleri bir yaşam tarzının başlamasına sebep olacaktır. Ebeveynler bebeklerinin sağlıklı olmadığı, bu sürecin kalıcı bir durum olacağı ve üstesinden gelemeyecekleri duygusuna kapılabilirler. Bu duyguya kapılan ebeveynler de ise öfke, anksiyete, ağır depresyon, suçluluk ve özgüven yetersizliği gibi tepkiler görülür (4). Planlanan doğum tarihinden önce gerçekleşen erken doğum da, bebeğin fiziksel matüretesini tamamlayamaması sebebi ile kuvöz ihtiyacı, solunum desteği ve ailesinin bebeği ile yeterince etkileşime girecek zaman bulamamasına yol açabilmektedir. Yenidoğan yoğun bakım ünitesinin ailelerde uyandırdığı ürkütücü ses, 1şıklar, yabancı ortamın yanında bebeğin iyileşmeyeceği veya kaybedileceği korkusu ailede panik, korku ve depresyon gibi negatif duygu durum değişikliklerine sebep olabilmektedir (5).

Doğum sonrası bebeğini kucağına alan anne için başlayan lohusalık dönemi; bağışıklık sisteminin zayıf olduğu, vücutta $\mathrm{y} 1 \mathrm{k} 1 \mathrm{~m}$ ve yeniden yapılanmanın olduğu, hormonların değişim gösterdiği fizyolojik bir dönemdir (2). Prematür doğumlarda, postpartum ile ilişkili stres faktörlerinin yanında yenidoğanın hastaneye yatırılması, bebek anne etkileşiminin bozulmasına ve annede sinirlilik, ağlama nöbetleri, kaygı gibi duygusal tepkilere yol açabilmektedir (6). Yenidoğanın yoğun bakım ünitesinde tedavi aldığı dönemlerde anne- bebek etkileşiminin azalması ve annenin kendisini mutsuz hissetmesine bağlı olarak bebeğine olan ilgisinin azaldı ${ }_{1}$ kaçınılmaz bir hal alır (7). Bebeğin hastanede yatırılarak tedavi edilmesi, annenin bebeğinden ayrı olması ve bebeğin bakımını kendisinin yapamaması annelerde anksiyete (8-10), mutsuzluk (11), hüzün ya da boşluk duygusu (12) ve duygusal küntlük ya da duyarsızlık (13) gibi emosyonel semptomlarda artışa sebep olmaktadır. Yenidoğanın medikal tedavisi devam ederken ebeveynlerin bu zorlu durum ile baş edebilmeleri için hemşirelerin bebeğin hastalığı, tedavi şekli ve süreci hakkında bilgi vermesi, aile merkezli bütüncül bir yaklaşım benimsenmesi, ebeveynlerin sorularını sabırla dinlemesi önerilmektedir (6,14-17).

Literatürde yenidoğan yoğun bakım ünitesinde bebeği tedavi altında olan ebeveynlerin bu zorlu süreçte yaşadıkları psikososyal sorunları ile ilgili yapılan nitel çalışmaların sınırlı olduğu görülmektedir $(13,15,17)$. Bu araştırma, bebeği yenidoğan yoğun bakım ünitesinde tedavi altında olan ebeveynlerin yaşadıkları psikososyal sorunlar ve başa çıkma yöntemlerini belirlemek amacıyla yapılmıştır. Araştırmada nitel araştırma yöntemlerinden "derinlemesine görüşme" yönteminin kullanılması ebeveynlerin yaşadıkları deneyimle ile ilgili duygu, düşünce ve algılarını derinlemesine değerlendirme olanağı sağlamıştır.

\section{GEREÇ VE YÖNTEMLER} Araştırmanın Evreni ve Örneklemi

$\mathrm{Bu}$ araştırma nitel araştırma yöntemlerinden "derinlemesine görüşme" tekniğinin kullanıldığı tanımlayıcı bir araştırmadır. Araştırmanın evrenini Düzce Üniversitesi Araştırma Hastanesi Yenidoğan Yoğun Bakım Ünitesi'nde yatan bebeklerin anneleri oluşturmaktadır. Örneklemi ise Mart-Haziran 2018 tarihleri arasında yenidoğan yoğun bakım ünitesinde yedi gün ve daha fazla kalan bebeklerin anneleri oluşturmuştur. Araştırma kriterlerine uyan çalışmaya katılmaya gönüllü olan toplam 25 anne ile derinlemesine görüşme yapılmıştır. Veri doygunluğundan ve cevaplar tekrara düşmeye başladığ 1 için 25 anne ile sinırlandırılmıştır.

Yenidoğan yoğun bakım ünitesi 10 yatak kapasitelidir ve toplam 13 hemşire görev yapmaktadır.

\section{Araştırmanın Etik Boyutu}

Araştırmanın gerçekleştirilebilmesi için Düzce Üniversitesi Klinik Araştırmalar Etik Kurulu'ndan (No: 2018\46) ve Düzce Üniversitesi Hastanesi'nden yazılı izin alınmıştır. Araştırma hakkında bilgilendirilme yapıldıktan sonra gönüllü olarak katılmayı kabul eden annelerden ve hemşirelerden yazılı izin alınmıştır. Annelere görüşmenin verileri ve kişisel kimlik bilgilerinin gizli kalacağı açıklanmıştır.

\section{Veri Toplama Araçları}

Araştırmanın verileri "Kişisel Bilgi Formu" ve Yarı Yapılandırılmış "Niteliksel Görüşme Formu" aracılığı ile oluşturulmuştur.

Kişisel bilgi formu: Araştırmacılar tarafından ilgili literatür taranarak hazırlanan formda araştırmaya katılan annelerin yaş, eğitim düzeyleri, çocuk sayıları, doğum sonrası destek alma durumu, bilgilendirme durumu gibi sosyo-demografik özelliklerini içeren bilgilere yer verilmiştir (18-20).

Niteliksel Görüşme Formu: Araştırmada görüşmeye yol göstermesi ve rehberlik etmesi amacıyla araştırmacılar tarafından hazırlanmış olan yarı yapılandırılmış form 
kullanılmıștır. Formda katılımcıların araștırma konusu ile ilgili duygu, düşünce, algı ve tutumlarını belirlemek için açık uçlu sorular bulunmaktadır. Görüşme formu konu ile ilgili geniş bir literatür taramasından sonra geliştirilmiştir (5,18-21). Formun kapsam geçerliği için eğitim bilimleri, psikiyatri hemşireliği ile çocuk sağlığı ve hastalıkları hemşireliği alanında doktora unvanına sahip altı uzman görüşü alınmıştır. Uzmanlardan gelen önerilere göre iki sorunun sorulma tarzı değiştirilmiş ve ek bir soru daha eklenmiştir. Görüşme formunda sorulardan bazı örnekler; Bebeği Yenidoğan Yoğun Bakım Ünitesi'nde yatan bir anne olmayı anlatır misınız?, Bebeğinizin Yenidoğan Yoğun Bakım Ünitesi'ne yatışından sonra aile hayatınızda yaşadığınız değişiklikleri anlatır mısınız?. Form belli bir sıra takip edilmeden görüşmenin akışına uygun olarak kullanılmıştır.

\section{Veri Toplama Yöntemi}

Araştırmanın verileri Mart-Haziran 2018 tarihleri arasında, nitel araştırma yöntemlerinden niteliksel (derinlemesine) görüşme yöntemi kullanılarak oluşturulmuştur. Görüşmeler araştırmacı tarafından yüz yüze görüşme yöntemi ile yapılmıştır. Görüşme planlanan annelerden uygun yer ve zaman için randevu alınmıştır. Görüşme sırasında kendilerini en rahat hissedecekleri bir yer olması için görüşme yeri seçimi annelere bırakılmıştır. Annelerin tercihleri doğrultusunda görüşmeler uygun oldukları bir zamanda servisteki eğitim odasında gerçekleştirilmiştir. Görüşmelerin kaliteli geçmesi açısından gürültüden arındırılmış ve katılımcının yalnız kalacağı bir ortamda oluşturulmasına dikkat edilmiştir. Görüşmenin yapılacağı ortamda önce görüşmenin amacı açıklanmıştır. Katılımcılardan görüşmenin yaklaşık ne kadar süreceği, ses kaydının hangi nedenle yapıldığı ve görüşmeden elde edilen tüm verilerin gizli olacağ alınmıştır. Ses kayıt cihazı ile yapılan görüşme sırasında katılımcılara istedikleri zaman ses kayıt cihazını kapatabilecekleri söylenmiştir. Katılımcılarla iletişimi kesmemek için cevaplara yönelik ve davranışları ile ilgili gözlem notları alınmıştır. Her bir katılımcı ile yapılan görüşme yaklaşık 40-50 dakika sürmüştür.

Görüşme sürecini yürüten araştırmacı psikiyatri hemşireliği yüksek lisans öğrencisidir. Araştırmacı derinlemesine görüşme yöntemi ile ilgili eğitim almış ve görüşmeleri süpervizyon alarak yürütmüştür.

\section{İstatistiksel Analiz}

Veriler tematik analiz yöntemi ile değerlendirilmiştir. Yarı yapılandırılmış soru formunda sorulan her bir soruya ilişkin yazılı ve sözlü olarak toplanan veriler görüşme sırasında tutulan gözlem notları değiştirilmeksizin bilgisayar ortamına aktarılmıştır. Görüşlerin ve notların araştırmanın amacına uygun olup olmadığı kontrol edilmiş ve araştırmanın amacı dışında herhangi bir görüş belirtilmediği saptanmıştır. Görüşler, anlamsal olarak benzerliklerine göre birleştirilmiş ve bu görüşleri temsil edebilecek kod isimleri oluşturularak her bir kod altında birleştirilen görüşlerin yazılış sıklığı belirtilmiştir. Kodlar anlam bütünlüğüne göre gruplandırılmış ve bu kodları temsil edebilecek, tema isimleri oluşturulmuştur.

Verilerin analizinin güvenirliğini arttırmak için, araştırmacılar kodların ve temaların oluşturulmasında birbirinden bağımsız çalışmıştır. Daha sonra bir araya gelerek, yapılan analizler tartışılmıştır. Verilerin analizinin geçerliğini sağlamak için, bir uzman ve araştırmaya katılan beş katılımcı ile görüşülmüştür. Onlara araştırmacılar tarafından belirlenen kodların ve temaların uygun olarak belirlenip belirlenmediği sorulmuştur. Uzman ve katılımcı görüşü alınarak tablolara son şekli verilmiştir (22).

\section{BULGULAR \\ Demografik özellikler}

Çalışmaya katılan annelerin yaş ortalaması 29.24'tür. Annelerin \%44'ü lise, \%36'sı ilkokul, \%20'si yüksekokul mezunudur. Annelerin \%80'i ev hanımı, \%44’ü orta gelir düzeyindedir. Çalışmaya katılan annelerin bebeklerinin yoğun bakımda yatma nedenleri preterm doğum, hiperbilirunemi, konjenital hastalıklardır. Bebeklerin \%56'sı erkek, \%44'ü ise k1zdır. Bebeklerin gestasyon haftaları 31 hafta ile 42 hafta arasında değişmektedir.

\section{Tema ve Alt Temalar}

Tematik analiz sonrasında, annelerin ifadeleri şu temalar altında toplanmıştır (Tablo 1).

\section{Tema 1. Yoğun bakıma bebeğini bırakmış anne olmak} Annelerin hepsi doğum sonrası bebeğini henüz göremeden yoğun bakıma alınmasından dolayı oldukça üzgün olduklarını bildirmişlerdir. $\mathrm{Bu}$ temada anneler kendi duygu ve düşüncelerini rahat bir şekilde ifade etmişler ve zaman zaman ağlamışlardır. Bu tema üç alt tema ile açıklanmıştır.

\section{Alt Tema 1. Boş kucak}

$\mathrm{Bu}$ alt temada annelerin hepsi doğum yapmış olmalarına rağmen bebeklerinin kucaklarında olmamasını çok büyük bir acı olarak tanımladılar. Özellikle diğer doğum yapan anneleri ve bebeği yanında olan anneleri görünce büyük üzüntü yaşadıklarını bildirmişlerdir. Aynı zamanda annelerin hepsi bebeksiz eve gitmenin çok güç olduğunu bildirmiştir.

Yalnız hissediyorsun eve çıktığında boşsun bebek yanında yok. Yani hiç bir şey hissedemiyorsun kucağına alamayınca. Kucă̆ına alıp onun sicaklığını hissetmek istiyorsun. Onun kokusunu aldığında daha farklı oluyor. Uzaktan öyle boş boş izliyorsun. (Katılımcı 17).

Bebeğim yanıma gelmeyince çok üzüldüm, nasıl desem yanım boştu kucă̆ım boştu... Herkes geldi gitti yanım boştu açıkçası...(Katılımcı 13)

Yani çocuk olmuş olmamış gibi var yok arası gibi oluyor, kucağım boş kaldı, kucăgın boş eve gitmek zaten ölüm gibi... (Katılımcı 14).

Çok kötüydü hep ăgllyordum. Ben servisteydim, gelip bebeğimi aldılar, aklım başımda değildi. Anlamadım ne olduğunu... Baktım orada yatıyordu sonra servise gittim ama çok ağladım. Yıkıldım yani ben burada, o orada. Kendimi çok kötü hissettim (Katılımcı 15).

Yani çok zor... Kucağın boş olunca, yani nasıl desem orda karşıdan baklyorsun sadece bacaklarını görüyorsun yüzünü bile göremiyorsun o benim çok zoruma gitti. Doğumdan sonra emzirmeden aldilar benden... Sadece bacakları çekilmiş bir fotoğraf var elimde sürekli ona bakıyorum... (Katılımer 5).

\section{Alt Tema 2. Camın arkasındaki annelik}

Annelerin hemen hepsi doğum sonrası hayal ettikleri anneliği şimdi camın arkasında yapmak zorunda kaldıklarını ifade ettiler. Annelerin büyük çoğunluğu $(n=18)$ bebeklerini sadece camın arkasından görebildiklerini, dokunamadıklarını ve kokusunu 
Tablo 1. Temalar, Alt Tema ve Kodlar

\begin{tabular}{|c|c|}
\hline Major katogeriler (Kategori) & Kodlar \\
\hline \multicolumn{2}{|l|}{ Tema 1. Yoğun bakıma bebeğini bırakmış anne olmak } \\
\hline Alt Tema 1. Boş kucak & $\begin{array}{l}\text { Doğum yaptım ama bebeğim yanımda değil } \\
\text { Kucağım boş kaldı } \\
\text { Bebeğimi hiç görmedim bile } \\
\text { Bebeksiz eve gitmek çok acı }\end{array}$ \\
\hline Alt Tema 2. Camın arkasındaki annelik & $\begin{array}{l}\text { Bebeğimi sadece cam arkasından görüyorum } \\
\text { Emziremiyorum, } \\
\text { Anne sütünü alışını bile camdan izliyorum } \\
\text { Cam arkasından bebeğimin kokusunu alamıyorum } \\
\text { Cam arkasından annelik yapıyorum }\end{array}$ \\
\hline Alt Tema 3. Bedenimin Eksilen Parçası & $\begin{array}{l}\text { Sanki bi bacağımı orda bırakmışım gibi } \\
\text { Sanki iç organlarımı orda bırakmışım gibi } \\
\text { Tarif edilemeyecek kadar büyük bir acı } \\
\text { Daha önce böyle bir acı yaşamamıştım. } \\
\text { Kelimelerle anlatamam } \\
\text { Sanki boşluktayım } \\
\text { Her anım bebeğimi düşünerek geçiyor }\end{array}$ \\
\hline \multicolumn{2}{|l|}{ Tema 2. Endişe Denizi } \\
\hline Alt Tema1. Ya... olursa & $\begin{array}{l}\text { Ya bebeğimi kaybedersem } \\
\text { Ya kötü haber alırsam } \\
\text { Ya bebeğime iyi bakamazsam } \\
\text { Ya kalıcı hasar kalırsa }\end{array}$ \\
\hline Alt Tema 2. Suçlu ben miyim? & $\begin{array}{l}\text { Keşke daha iyi beslenseydim } \\
\text { Keşke kendime daha iyi baksaydım } \\
\text { Keşke kendimi yormasaydım }\end{array}$ \\
\hline Alt Tema 3. Tanımlanamayan duygular & $\begin{array}{l}\text { Umut ve umutsuzluk arasında kalma } \\
\text { Ne hissetttiğini anlayamama } \\
\text { Belirsizlik } \\
\text { Sanki boşluktayım }\end{array}$ \\
\hline Tema 3. Destek sistemleri & $\begin{array}{l}\text { Eşin desteğini alma } \\
\text { Arkadaş desteğini alma } \\
\text { Aile/akraba desteğini alma } \\
\text { Desteği reddetme } \\
\text { Hemşire desteğini hissetme } \\
\end{array}$ \\
\hline Tema 4. Başa çıkma stratejileri & $\begin{array}{l}\text { Sürekli ağlama } \\
\text { Ağlayarak rahatlama } \\
\text { Başkaları ile konuşma } \\
\text { Olumlu düşünmeye çalışarak rahatlama } \\
\text { Dua etme } \\
\text { Allah'a sığınma } \\
\end{array}$ \\
\hline \multicolumn{2}{|l|}{ Tema 5. Beklentiler } \\
\hline Alt Tema 1. Sağlık çalışanlarından beklentiler & $\begin{array}{l}\text { Hemşirelerin sorulara yanıt vermeleri } \\
\text { Hemşire/hekimin bilgilendirmesi } \\
\text { Hemşire/hekimden anlayışlı, ilgili olmalarını bekleme } \\
\text { Hemşirelerin bebeğe dokunmaya izin vermelerini isteme }\end{array}$ \\
\hline Alt Tema 2. İlişkide bulundukları diğer kişilerden beklentileri & $\begin{array}{l}\text { Teselli konuşmaları yetmediğini düşünme } \\
\text { Moral verici, olumlu sözler ile destek bekleme }\end{array}$ \\
\hline \multicolumn{2}{|l|}{ Tema 6. Aile hayatındaki değişimler } \\
\hline Alt tema 1. Ev Rutininin Bozulması & $\begin{array}{l}\text { Evdeki diğer çocuğun bakımının etkilenmesi } \\
\text { Tüm aile üyelerinin stres düzeyinin yüksek olması } \\
\text { Aile üyelerinin stres ve baskısını hissetmek } \\
\text { Evde normal işleyişin değişmesi }\end{array}$ \\
\hline Alt Tema 2. Eş Ilişkisinin Güçlenmesi & $\begin{array}{l}\text { Eş ile ilişkinin olumlu yönde değişmesi } \\
\text { Eş ilişkisinin güçlendiğini hissetme } \\
\text { Eşinin olgunlaştı̆ğını düşünme } \\
\text { Eş ile duygusal bağının güçlendiğini hissetme }\end{array}$ \\
\hline
\end{tabular}


alamadıklarını; bazıları emziremediklerini $(n=10)$, bazıları ise $(n=8)$ bebeklerine camın arkasında bir yabanc1 gibi bakmaktan dolayı mutsuz olduklarını bildirmiştir.

Kelimesi yok ki onun gerçekten çok zor. Beklediğin, hayalini kurduğun bebek yanında yok. Görüyorsun, dokunamıyorsun, hazırladıklarını (kıyafetler) kokluyorsun (Katılımcı 16).

Hiç kucağıma alamadım mesela. Günde bir kere olsun, kucă̆ıma almayı birkaç saniye ya da bir dakikada olsa öpüp koklamayl isterdim. Ona dokunmayı isterdim (Katılımcı 20).

Çok kötü yani bir anne için en kötü duygulardan bir tanesi böyle evladını kucağına alamadan cam arkasından görmek. Doğum sonrası hiç kucă̆ıma almadım, sadece gösterdiler annesi biz götürüyoruz dediler (Katılımcı 20). Ama o camın önünde olmak hiç güzel bir şey değil, çok iğrenç. Anne olmak nasıl bir şey dediklerinde tarifsiz diyorlar ya... ben daha anlayamadım nasılmış annelik...(Katılımci 11).

Yanına girip dokunmayı çok istedim. En azından birkaç dakika onu yakından görebilseydim, kucağıma alabilseydim, koklayabilseydim gerçekten istedim. Çünkü doğum esnasında yüzünü gördüm ama net göremedim, doğru düzgün kendimde değildim, yorgunluğum vardı bir de ben yatıyordum o yukarıdaydı pek seçemedim bile yüzünü... (Katılımcı 12).

Mesela emzirmek isterdim en azından bir kere bir kere yakından görmek isterdim...(Katılımcı 11).

Alt Tema 3. Bedenimin Eksilen Parçası

Annelerin hemen hepsi $(\mathrm{n}=23)$ yaşadıkları bu anların hayatları boyunca yaşadığı en büyük acı deneyimi olduğunu ifade etti. Annelerin yarısından fazlası $(n=14)$ bu acı deneyimini tarif edecek kelime bulamadıklarını ifade ederken, bazıları ise $(n=5)$ bedenlerinden bir parçasını bırakmış gibi hissettiklerini ifade etmiştir.

Çok üzüldüm yani o kadar çok üzüldüm ki. Sonra odaya geçtim hani çocuğum yok sanki böyle ölmüş gibi oldum (Katılımcı 4).

Işste geldim içeriye almayınca camdan sadece görüyorsun. Sanki ayağımın bir parçasını oraya koymuşlar gibi, yürüyemiyor gibi hissediyordum (Katılımci 11).

Ya bi parçam yok diyebilirim yani bi yanım yok çok boşluktayım ne bileyim büyük bir şey sanki... Eksik bende şu anda (Katılımcı 10)

Sanki bütün iç organlarınızı o kuvözün içine bırakmış, eve boş bir anne olarak gitmiş gibi oluyorsunuz...(Katılımci 11).

Bir insanın kaldıracağ̀ bir şey değil kesinlikle değil çünkü evlat bu...! Anne baba eş dost değil ki evlat bu...! (Katılımcı 16).

\section{Ana Tema 2. Endişe Denizi}

Çalışmaya katılan annelerin hepsi bebeklerinin sağlığı ile ilgili yoğun endişe yaşadıklarını ifade etti. Annelerden sadece biri yoğun bakımda iyi bakılmadığı ile ilgili endişe bildirirken, iki anne maddi endişelerini bildirmiştir. Yaşadıkları bu endişeler üç ayrı alt tema ile tanımlanmıştır.

\section{Alt Tema1. Ya...olursa}

Annelerin ifade ettiği endişeleri genellikle ya...olursa şeklinde başlayan cümlelerden oluşmuştur. Annelerin yarısından fazlası dile getirmekten korktuğunu ancak bebeğini kaybetme korkusu ile başa çıkmakta çok zorlandığını ifade etti. Annelerin ifade ettiği diğer endişeler ise, bebeklerinde kalıcı hasar/sakatlık kalması $(n=15)$ ve bebeklerine iyi bir annelik yapamama $(n=10)$ ile ilgili idi.

Ya oradan çıkaramazsam, ya (suskunluk) diye çok korktum. Ya orada bir şey olursa eve getiremezsem?(Katılımcı 23).

Bebeğimi orada bakıyorlar mı diye, her ă̆ladı̆̆ında bebeğimi kucaklarına alıyorlar mı acaba, mamasını veriyorlar mı acaba diye aklımdan düşünceler geçiyordu (Katılımci 15).

Ya ölürse... çok korkuyorum (Katılımcı 9).

Kötü bir hastalık çımasindan korktum bide durumum kötü hani nasıl bakarım, nasıl tedavi ederim diye ondan çok korktum (Katılımcı 5).

\section{Alt Tema 2. Suçlu ben miyim?}

Annelerin yaklaşık yarısı $(n=12)$ bebeklerinin yoğun bakımda olma nedeni kendilerinin bir hatası olarak düşündüğünü ve kendilerini suçladığını ifade etti. Bazıları ise $(n=7)$ yakın çevresindeki insanların bu konuda kendilerini suçladığını ya da suçlama imasında bulunduğunu bildirdi.

Hani kendimi suçladım hani güzel tedavi görseydim hasta olmayacaktı diye. Kendimi suçladım çünkü doğru düzgün ilaç alamadım, durumum yoktu (Katılımcı 5).

Acaba benim yüzümden mi bu hale düştü ya da dışarıdakilerin söylemesi insanı çok etkiliyor. Zayıf olması mesela acaba doyuramadım mı? Acaba yeterli gelmedi mi? (Katılımci 8).

Benden kaynaklanan bir şey mi diye düşünüyorum. Bir yandan diyorum Allah vergisi. Hamileyken yetersiz mi beslendim, bir şey mi oldu diye düşündüm... (Katılımcı 21).

\section{Alt Tema 3. Tanımlanamayan duygular}

Annelerin büyük çoğunluğu (n=19) görüşme sırasında duygularını tanımlamada zorluk çektiğini ifade etti. Bazıları ( $\mathrm{n}=7)$ umutlu olduğunu, bazıları umutlu olduğunu ama bir yandan umut etmeye korktuğunu $(n=5)$, bazıları bir boşluğun içinde olduğunu ve duygu hissedemediğini $(\mathrm{n}=6)$ ifade etti.

Tabii ki sanki böyle bir boşlukta gibisin. Boşu boşuna niye hala acı çekiyorum, ya da niye bu sanclları çektim diye bir duygu oluyor çünkü. Değişik yani hislerim pek anlatamıyorum...(Katılımcı 2).

Hislerim yok oldu, yok ki... Kaybetme korkusu, görememe korkusu eksiksin yarımsın senin bir parçan orda onu burada bırakarak gitmek ölüm, yerinde duramıyorsun çok zor (Katılımcı 5).

\section{Tema 3. Destek sistemleri}

Annelere destek sistemleri sorulduğunda büyük çoğunluğu $(n=20)$ en büyük destek kaynağının eşi olduğunu ifade etti. Annelerin yarısından fazlası $(n=16)$ aile, arkadaş, akrabalarından tatmin edici destek aldığını ifade ederken bazıları $(n=5)$ hiç kimsenin desteğini istemediğini, desteği reddettiğini ifade etti. Destek istemeyen anneler, hiç bir desteğin gerçekçi olmadığını ve bebeğini geri getirmeyeceğini anlatırken; sadece dört anne, hemşire desteği aldığını ve bu destekten memnun olduğunu ifade etti.

$\mathrm{Bu}$ ifadelerden bazıları aşağıda verilmiştir: 
Kuzenlerime pek anlatmam ama ablalarıma anlatırım en çok. Onlardan her türlü desteğini allyorum, maddi manevi. Onların bana verdiği desteğin yeterli olduğunu düşünüyorum beni anladıklarını düşünüyorum (Katılımcı 7).

Hemşireler mesela. Beni daha çok hemşire ve doktorlar işte sen onların sözüne bakma süt emdikçe gelir gibi sözlerle motive ettiler. Onlar öyle söyledikçe ben kulak asmamaya başladım (Katılımcı 8).

Her şeyimi eşimle paylaşıyorum, onun desteği anlatılmaz ...(Katılımcl 15).

Stresli bir anneyi rahatlatabilecek tek şey evlat... Kimse değil! Bilmiyorum ben mi bir tek böyle düşünüyorum. Kim olursa olsun kardeşiniz, ablanız, dostunuz gelmiş eşiniz gelmiş konuşsalar bile dinlemiyorsunuz ki! Onlar dinleseniz de anlamıyorsunuz. Hiçbirinin desteği bebeğimi bana vermiyor...(Katılımcı 21).

Destek almak istemediğini bildiren anneler, teselli sözcüklerinin yetmediğini hatta bu sözcüklerin daha çok canını yaktığını ifade etti. Bu ifadelerden bazları aşağıldaki alıntılarda verilmiştir;

Isste iyi olacak teselli ettikçe ben daha kötü oluyordum. O yüzden öyle çok kimsenin konuşmasina izin vermedim. Aslında herkes destek oluyordu ama ben izin vermiyordum (Katılımcı 1).

Sevmiyorum böyle yalanct tesellileri, teselli bence bir işe yaramıyor çünkü. Benim duygularımı değiştirmiyor yani. Ben her durumda böyleyim zaten yalnı yaşamayı seviyorum, bu dönemde kimse rahatsiz etmesin yalniz biraksınlar beni. Yalnız derken hani ne bileyim sürekli aaa iyileşecek merak etme falan denmesine gerek yok yani...(Katılımci 9).

Düzelecek diyorlar beni rahatlatmak için yani doğumdan çıktığım zaman iyi falan dediler ama yakınlarımın gözlerinin dolduğunu görünce acaba öldü de bana mı söylemiyorlar diye düşündüm. Onların destekleri benim için yeterli olmuyor...(Katılımcı 14).

Tema 4. Başa çıma stratejileri

Annelerin baş etme yöntemi olarak en sık kullandığ yöntemlerin ağlama $(n=21)$, dua etme $(n=15)$, olumlu düşünme $(n=12)$ ve bir başkası ile konuşarak rahatlama $(n=10)$ olduğu belirlendi. Annelerin bazıları $(n=4)$ ağlamalarına engel olamadıklarını, özellikle gece bu nedenle uyuyamadıklarını ifade etti. Olumlu düşünerek kendini rahatlatmaya çalışan annelerin bazıları olumlu düşünmenin bir sihir gibi bebeklerine de yansıyacağını, bazıları $(n=4)$ ise olumsuz düşünmenin bebeklerinin sağlığını olumsuz etkileyeceğine inandığını bildirdi.

En göze çarpan ifade;

Her şeyin düzeleceğini düşünüyorum, her şey daha iyiye gidecek diye rahatlatıyorum yani kötü düşünmüyorum hep olumlu tarafina bakıyorum, kendi açımdan bakıyorum, olumlu düşündüğ̈̈mde rahatlyorum (Katılımci 18).

Aşağıdaki iki ifade de başa çıkma yöntemi olarak yalnızlığl tercih eden annelerin yalnızliğl tercih etme nedenleri görülmektedir:

Kendimle kalmayı tercih ettim. Telefonları bile açmadım yani. Acılarımı, duygularımı paylaşmayı sevmiyorum (Katılımcl 9).
Millet yanıma geliyordu ben hep ağllyordum. Ziyaretçileri görünce daha acı bir şekilde ă̆liyordum. Yalnız kalmak bana daha iyi geliyordu (Katılımcı 13).

Aşağıdaki ifadeler ağlama ve dua etme baş etme stratejini kullanan annelere aittir:

Yüreğimde inanç var. Dua ediyorum sadece yani güzel sağllklı olsun daha çok iyi olsun içim rahat ama tabi yanımda olsun istiyorum. Hani bi an önce çıksın yanıma gelsin. Hayal ediyorum onu. (Katılımcı 10).

Sadece ă̆ladım başka hiçbir şey yapmadım. Dua ettim ağladım. Işste bu beni rahatlatıyordu. En büyük çözüm olarak ben kendime bunu bulmuştum (Katılımcı 15).

\section{Tema 5. Beklentiler}

$\mathrm{Bu}$ temada annelerin beklentileri sağlık çalışanlarından ve ilişkide bulundukları diğer kişilerden beklentiler olarak iki alt temada incelenmiştir.

\section{Alt Tema 1. Săğlı çalışanlarından beklentileri}

Annelerin yaklaşık yarısı $(n=12)$ sağlık çalışanlarından beklentisini dile getirdi. $\mathrm{Bu}$ beklentiler; sorulan her soruyu cevaplamaları, bebeğini görmeye ve dokunmaya izin vermeleri ve anlayış̧ı olmaları ile ilgili idi. Ancak bu beklentileri ifade eden annelerin hepsi sağlık çalışanlarının da haklı olduğu noktaların olduğunu ve onları da anladıklarını bildirdi.

Bu ifadelerden bazıları:

Soru sordukça hemşirelerden güzel cevaplar almak çok rahatlatır. Onlar da yoğun çalışıyor ama hani bir anne olarak ters tepki alınca ister istemez etkiliyor yani... (Katılımcı 2).

Burdaki personelden tek bir cümle umuduyla koşa koşa geliyorsunuz kendi ăgrınız kendi sancınız varmış hiç birini düşünmüyorsunuz. Sadece tek bir cümle iyi bir şey duyabilmek umuduyla geliyorsunuz. Ama bazen iyi şeylerle karşılaşmayabiliyorsunuz. Bebeğimi daha yakından görmek istiyordum izin vermiyorlar, çok üzülüyorum...(Katılımcl 16).

\section{Alt Tema 2. İlişkide bulundukları diğer kişilerden} beklentileri

Annelerin yaklaşık yarısı ilişkide olduğu kişilerden duygusal beklentileri olduğunu $(n=12)$ ve duygusal destek alabildiğini, diğer yarısı $(n=11)$ beklenti içinde olduğu kişilerden duygusal destek alamadığını ifade etti. Anneler, bekledikleri duygusal desteği eş, aile üyeleri ve arkadaşlarından yeterince karşıladığını bildirdi.

$\mathrm{Bu}$ ifadelerden bazılar1;

Manevi olarak beklediğim hep karşılandı. Annem olsun, kardeşlerim olsun, eşim olsun. Hani sürekli yanımdalard yalnı bırakmadılar, ellerinden geleni yaptılar, duşuma bile yardımcı oldular, saçımı bile taramama yardımcı oldular (Katılımci 13).

Manevi olarak da bu durumda böyle stresli bir anneyi rahatlatabilecek tek şey evlat ki zaten. Kimse değil bilmiyorum ben mi bir tek böyle düşünüyorum (Katılımcı 16).

\section{Tema 6. Aile hayatındaki değişimler \\ Alt tema 1. Ev Rutininin bozulmast}

Annelerin büyük çoğunluğu yaşadıkları bu hastane deneyiminin ev rutinlerini etkilediğini, özellikle ev işleri ve evdeki diğer çocuğun bakımı konusunda sorun yaşadıklarını ifade etti.

$\mathrm{Bu}$ ifadelerden biri aşağıdaki gibidir: 
Evde her şey alt üst oldu, evin normal düzeni bozuldu. En çok da evdeki kızımın bakımı aksıyor diye üzülüyorum... (Katılımcı 10).

Bazı anneler ise $(n=7)$ evdeki tüm aile üyelerinin de yaşanan durumdan dolayı çok üzgün olduklarını ve evdeki iletişimi etkilediğini bildirmiştir.

Aşağıdaki iki ifade aile üyelerinin ruhsal etkilenimini anlatmaktadir:

Buhran... 93 harbi gibi. Her dakika gelen onu soruyor ben kendi acımı unuttum. Mesela kayınpederim geliyor bebek yok mu diyor. Sanki Allah muhafaza ölmüş gibi evde bir yas var. Hani bekleniyor ya, her şeyini almışlar bir de ilk torun ya her şey şatafatl böyle her şey lüks ama bebek yok. Hiç kimse konuşmuyor evin içinde herkes birbirine baklyor (Katılımcı 11).

Evdeki hayatım, yani mesela ben yatak odamda ağllyordum eşim bir odada, çocuklarım başka bir odada ăglıyorlardı çok kötü... (A ğlamaya başladı) (Katılımcı 15).

\section{Alt Tema 2. Eş ilişkisinin güçlenmesi}

Annelerin yarısından fazlası $(\mathrm{n}=16)$ aile hayatındaki diğer önemli bir değișimi de eş ilișkilerinde yaşadıklarını ifade ettiler. Bazı anneler bu süreçte $(n=7)$ eşlerinin olgunlaştığını, bazı anneler $(n=11)$ eşi ile birbirlerine daha çok bağlandığını, ilişkilerinin daha güçlendiğini hissettiğini bildirdi.

Aşağıdaki bazı ifadelerde de görüldüğü gibi eş ilişkilerindeki güçlenme, yaşanılan bu acı deneyimin bir anlamda kazancı gibi görülmektedir.

Biz daha güçlendik bence... En azından birlikte olduğumuzda aşabileceğimizi gördük. Lohusalık döneminde eşler arasında kopukluk oluyor diyorlar ya genelde ben ona katılmıyorum da daha çok bağlandık. Her şerde bir hayır var... (Katılımcı 11).

Mesela uzun zamandır aşkım falan demezdik ama mesajlaşırken aşkım kendini üzme demeye başladık, hani sanki daha çok duygusallaştık... (Katılımcı 18).

Yani duygu bağımız güçlendi bu durumda bizim. Belki çocuğumuz yatmasaydı bu kadar duygu bağımız olmayacaktı. Eve gittiğimizde ikimize zor gelecekti ama şuan belki bu çocuk yoğun bakıma yatınca şeyi anlamış olduk her şeyin başında să̆lı̆̆ın geldiğini. Aramızdaki bağın kuvvetlendiğini düşünüyorum öncekine oranla... (Katılımcı 18).

\section{TARTIŞMA}

$\mathrm{Bu}$ çalışma, bebeği yenidoğan yoğun bakım ünitesinde tedavi altında olan annelerin yaşadıkları psikososyal sorunlar ve başa çıkma yöntemlerinin belirlenmesi amacı ile yapılmıştır.

Çalışmada en dikkat çekici ve duygu yoğunluğu yüksek olan temalardan biri "yoğun bakıma bebeğini bırakmış anne olmak" teması olduğu görülmektedir. Anneler, doğumdan sonra bebeklerini hiç görememe, bebeğini hiç kucağına alamama, dokunamama, emzirememe ve sadece camın arkasından görme kısacası annelik yapamamanın büyük üzüntü yarattığını ifade etmişlerdir. Bu bulgulara benzer olarak Şahin ve ark. (18) bebekleri yoğun bakımda yatan 21 ebeveynle yaptığı çalışmada; bebeğine dokunamama, emzirememe, bebeğini hastanede birakarak taburcu olmanın ebeveynlerin en yoğun yaşadığ stresörler olduğunu belirtmiştir. Postpartum dönemin getirdiği duygusal değişimler ile birlikte annelerin yaşadığı bu zorlu deneyim onların başa çıkmakta zorlandıkları duygular yaşamalarına neden olmaktadır. Çalışmada ortaya çıkan en belirgin duyguların yoğun endişe, korku ve suçluluk olduğu görülmektedir. Suçluluk duygularının daha çok bebeğinin yoğun bakımda olmasının kendisinin bir rolü olduğunu düşünme, korku ve endişenin ise bebeğinin sağlığı ile ilgili kötü haber alma ile ilgili olduğu görülmektedir. Konukbay ve ark.'nın (20) yaptığı tanımlayıcı çalışmada, aileler yoğun bakımda bebeğinin durumunun belirsizliği ve çocuklarını yoğun bakım ünitesinde istediklerinde görememenin duygusal güçlük yaşattığı ortaya çıkmıştır. İlgili literatürde de annelerin sağlık çalışanlarından beklentilerinin bebeklerinin sağlık durumuyla ilgili yeteri kadar bilgi alma ve bebeğini istediği zaman ziyaret edebilme olarak bildirilmektedir (23-25). Yapılan başka bir çalışmada ebeveynlerin gereksinimleri incelendiğinde öncelikli olarak yakınlık olduğunu belirtmiş olup bunu destek ve güven duygusu izlemiştir (19). Bizim çalışmamızda da özellikle ebeveynler sağlık çalışanlarından yakınlık ve destek olmalarını beklediklerine dair bildirimlerde bulunmuşlardır.

Çalışmada annelerin kullandıkları başa çıkma yöntemleri önceki araştırmalara benzerlik göstermekte olup sıklıkla ağlama, dua etme, olumlu düşünme, başkasıyla konuşarak rahatlama gibi yöntemlerin kullandıkları ortaya çıkmıştır $(18,23,26)$. Çalışmamızdan farklı olarak aynı hastalığa sahip bebeklerin ebeveynleriyle görüşmenin stres düzeylerini azalttığını bildiren çalışmalara da rastlanmıştır $(23,26)$. Hemşirelerin bebekleriyle ilgili onlara bilgi vermesi, bebeğini göstermesi ve güler yüzlü davranmalarının ebeveynlerde streslerinin azaldığını eve daha huzurlu gittiklerini ifade etmişlerdir. Literatürde ebeveynlerin stresle baş etmesinde hemşire desteğinin ailelere büyük katkı sağladığı bildirilmektedir $(25,27,28)$. En önemli hemşire desteği olarak bebeğin sağlık durumu ile ilgili bilgilendirme olduğu ve bilgilendirmenin annelerin kaygı ve umutsuzluk düzeylerinin azalmasında oldukça etkili olduğu ortaya konmuştur (4,29-31). Yurtdışında yapılan bir çalışmada preterm bebeklerin ailelerine verilen erken eğitim ve duygusal desteğin streslerini azalttığını belirtmiştir $(32,33)$. Yapılan başka bir çalışmada prematüre bebeği yoğun bakımda yatan ailelerin yüksek oranda stres yaşadığı ve bu tarz ailelerin ihtiyaçlarını belirlemek ve karşılamak için aile merkezli yaklaşımı önerilmiştir (34). Yenidoğan yoğun bakımda yatan bebeklerin ebeveynlerinin duygudurum ve kayg1 belirtilerinin belirlenmesi, risk altındaki veya etkilenen ebeveynlere yönelik müdahalelerin yapılmasında hemşireler rol almalıdır (35). Özellikle bebeklerle birebir ilgilenen yenidoğan yoğun bakım hemşirelerinin ailelerle iletişim kurarak ihtiyaçlarına yönelik eğitimler düzenleyip stresle baş etmelerinde yardımcı olunmalıdır. Yurtdışında yapılan çalışmalarda yenidoğan yoğun bakımda yatan bebeklerin aile merkezli bakımla ebeveynlerin kaygı ve stresinin azaldığını, memnuniyet oranlarının yükseldiği belirtilmiştir (36). Çalışmamızda annelerin sağlık çalışanlarından beklentileri bebeklerinin sağlık durumları ile ilgili yeterli bilgi almak olduğu görülmektedir. Anneler manevi destek beklentilerinin olmamasını, hiçbir sözcüğün veya konuşmanın kendilerini rahatlatmaya yetmeyeceğini düşünmelerine bağlamışlardır. 
Literatürde yenidoğan yoğun bakımda yatan bebeklerin aileleriyle yapılan nitel bir çalışmada ebeveynlerin aile, iş, sosyal hayat ve psikolojilerinin olumsuz etkilendiğini ifade ettiklerini belirtmişlerdir (26). Bizim çalışmamızda da "aile hayatının etkilenmesi" ana temasında görüldüğü gibi ev rutininin bozulduğu ve tüm aile üyelerinin de bu süreçten olumsuz etkilendiği ortaya çıkmıştır. Aynı temada anneler bu yaşanan kriz durumunu eş ilişkilerini güçlendiren ve duygusal bağları güçlendiren bir deneyim olarak tanımlamışlardır. Benzer şekilde hastane deneyiminin ev rutinini bozduğunu ve aile içi ilişkilerinde değişiklik olduğunu ifade etmişlerdir (18). Yurt dışında yapılan başka bir çalışmada erken doğan bebeklerin yoğun bakıma yatırılmasının stresli bir durum olduğu ve ailelerin bu durumdan etkilendiği vurgulanmıştır (38).

\section{SONUÇ}

$\mathrm{Bu}$ araştırmada ebeveynlerin yaşadıkları zorlu deneyimlerini ve başa çıkma stratejilerini altı ana tema ile tanımlanmıştır. Bu ana temalar; yoğun bakımda bebeğini bırakmış anne olmak, endişe denizi, baş etme stratejileri, beklentiler, aile hayatındaki değişimler ve destek sistemleridir. Sonuç olarak katılımcıların, hiç hayal etmedikleri şekilde yaşadıkları bu süreci zorlu bir annelik deneyimi olarak tanımladıkları, bu deneyime yoğun endişe ve suçluluk ile duygusal tepki verdikleri, aile hayatında değişimlerden olumsuz etkilendikleri, yoğun bakım ünite hemşirelerinden ve kendi ailelerinden destek beklentileri olduğu ve duygusal başa çıkma stratejileri kullandıkları söylenebilir.

Yenidoğan yoğun bakım ünitesinde bebekleri yatan ebeveynlerin hemşirelik desteğinin karşılaştıkları zorluklarla baş edebilmesinde önemli olduğu söylenebilir. $\mathrm{Bu}$ dönemde birçok stresörlerle karşılaşılan ebeveynlerin karşılaştıkları streslerle baş edebilmeleri için yenidoğan yoğun bakım hemşireleri tarafından bireysel ya da grup eğitimleri düzenlenebilir. Çalışmanın sonucunda annelerin bebeklerinin yanında olma, bakımına katılma gereksinimleri olduğu anlaşılmıştır. Ailelerin bebeklerini daha fazla görebilmelerini sağlayacak gerekli düzenlemelerin yapılması ve bu konuda hastane yönetimi ile işbirliği sağlanması yararlı olabilir.

\section{KAYNAKLAR}

1. Çelebioğlu A. Yenidoğanın hastaneye kabulünde ebeveynlerin duyguları ve hemşirelik yaklaşımı. Uluslararası İnsan Bilimleri Dergisi. 2004; 1(1): 1-37.

2. Küçükoğlu S, Çelebioğlu A, Coşkun D. Yenidoğan kliniğinde bebeği yatan annelerin postpartum depresyon belirtileri ve emzirme öz yeterlilik düzeylerinin belirlenmesi. Gümüşhane Üniversitesi Sağlık Bilimleri Dergisi. 2014; 3(3): 921-32.

3. Beydağ DK. Doğum sonu dönemde anneliğe uyum ve hemşirenin rolü. TSK Koruyucu Hekimlik Bülteni. 2007; 6(6): 479-84.

4. Çavuşoğlu H. Hastaneye Yatmanın Çocuk ve Aile Üzerindeki Etkileri: Çavuşoğlu H, editör. Çocuk Sağlığı Hemşireliği. Ankara; 2008. p. 51-6.

5. Erdeve Ö, Atasay B, Arslan S. Yenidoğan yoğun bakım ünitesinde yatış deneyiminin aile ve prematüre bebek üzerine etkileri. Çocuk Sağlığı ve Hastalıkları Dergisi. 2008; 51(2): 104 -9.
6. Çelebioğlu A, Polat S. Hiperbilirubinemi nedeniyle hastaneye yatırılan yenidoğanların annelerinin kayg1 düzeyi, etkileyen faktörler ve bilgilendirmenin kaygıyı azaltmadaki rolü. Atatürk Üniversitesi Hemşirelik Yüksekokulu Dergisi. 2008; 11(2): 47-54.

7. Wigert $H$, Johansson $R$, Berg $M$, Hellström AL. Mothers'experiences of having their newborn child in a neonatal intensive care unit. Scandinavian Journal of Caring Sciences. 2006; 20(1): 35-41.

8. Doering LV, Moser DK, Dracup K. Correlates of anxiety, hostility, depression, and psychosocial adjustment in parents of NICU infants. Neonatal Network. 2000; 19(5): 15-23.

9. Padovani FH, Linhares MB, Carvalho AE, Duarte G, Martinez FE. Anxiety and depression symptoms assessment in pre-term neonates' mothers during and after hospitalization in neonatal intensive care unit. Revista Brasileira De Psiquiatria. 2004; 26(4): 251-4.

10. Erdem Y, Kutluk Ş. Doğum sonu bebekleri yoğun bakım ünitesinde yatan annelerle, yanında olan annelerin kayg1 düzeylerinin karşılaştırılması. 13. Ulusal Neonatoloji Kongresi ve Yenidoğan Hemşireliği Kongresi; 13-17 Nisan 2005; Kayseri. s. 480 .

11. Shellabarger SG, Thompson TL. The critical times: meeting parental communication needs throughout the NICU experience. Neonatal Network. 1993; 12(2): 39-45.

12. Fegran L, Helseth S, Fagermoen MS. A comparison of mothers'and fathers' experiences of the attachment process in a neonatal intensive care unit. Journal Of Clinical Nursing. 2008; 17(6): 810-6.

13. Hall EOC. Being in an alien world: Danish parents' lived experiences when a newborn or small child is critically ill. Scandinavian Journal of Caring Sciences. 2005; 19(3): 179-85.

14. Ward K. Perceived needs of parents of critically ill infants in a neonatal intensive care unit. Pediatric Nursing Journal. 2001; 27(3): 281-5.

15. Fowlie PW, McHaffie H. Supporting parents in neonatal unit. British Medical Journal. 2004; 329(7478): 1336-8.

16. Ergin D, Şen N, Demet M. Yenidoğan ünitesinde tedavi gören bebeklerin ebeveynlerinin anksiyete ve kayg1 düzeyleri ve bunları etkileyen etmenler. 1. Ulusal Pediatri Hemşireliği Kongresi, 21-23 Haziran 2007; İzmir. s. 55.

17. Turan T, Başbakkal Z, Özbek Ş. Effect of nursing interventions on stressors of parents of premature infants in neonatal intensive care unit. Journal of Clinical Nursing. 2008; 17(21): 2856-10.

18. Şahin HN, Oskay Ö. Prematüre bebekleri yenidoğan yoğun bakım ünitesinde yatan ebeveynlerde ortaya çıkan stresörler. Çocuk Dergisi. 2008; 8(2): 108-13.

19. Küçükoğlu S, Aytekin A, Gülhaş NF. Yenidoğan yoğun bakım ünitesinde bebeği yatan annelerin gereksinimlerinin belirlenmesi. Hemşirelikte Eğitim ve Araştırma Dergisi. 2015; 12(3): 182-8.

20. Konukbay D, Arslan F. Yenidoğan yoğun bakım ünitesinde yatan yenidoğan ailelerinin yaşadığ güçlüklerin belirlenmesi. Anadolu Hemşirelik ve Sağlık Bilimleri Dergisi. 2011; 14(2): 16-22. 
21. Top FÜ, Alemdar DK. Fenilketonürili çocuğu olan ailelerinin yaşadıkları güçlükler: Niteliksel bir çalışma. Hemşirelikte Eğitim ve Araştırma Dergisi. 2015; 12(1): 62-8.

22. Yıldırım A, Şimşek H. Sosyal bilimlerde nitel araştırma yöntemleri. 7. baskı. Ankara: Seçkin Yayıncılık; 2008.

23. Çalışır H, Şeker S, Güler F, Anaç GT, Türkmen M. Yenidoğan yoğun bakım ünitesinde bebeği yatan ebeveynlerin gereksinimleri ve kaygı düzeyleri. Cumhuriyet Üniversitesi Hemşirelik Yüksekokulu Dergisi. 2008; 12(1): 31-44.

24. Martha AQ Curley, Patricia A. Moloney-harmon caring practices: The impact of theoretical care experience on the family: Critical care nursing of infants and children. Philadelphia: W.B. Saunders Co; 2001. p. 1-128.

25. Sönmez S. Pediatrik yoğun bakım ünitesinde çocuğu yatan ailelerin saptadıkları gereksinimlerin hemşireler tarafindan algılanması [Doktora tezi]. İzmir: Ege Üniversitesi Sağlık Bilimleri Enstitüsü; 2002.

26. Çekin B. Bir üniversite hastanesi yenidoğan yoğun bakım ünitesinde prematüre bebeği yatan ebeveynlerin stress düzeyi ve başetme yöntemleri [Yükseklisans tezi]. Denizli: Pamukkale Üniversitesi Sağlık Bilimleri Enstitüsü; 2014.

27. Akkoyun S, Arslan FT. Investigation of stress and nursing support in mothers of preterm infants in neonatal intensive care units. Scandinavian Journal of Caring Sciences. 2018; 32(4): 1-8.

28. Miles MS, Carlson J, Funk SG. Sources of support reported by mothers and fathers and of infants hospitalized in a neonatal intensive care unit. Neonatal Network. 1996; 15(3): 45-52.

29. Özyazıcıŏlu N, Tüfekci F. Yenidoğan yoğun bakım ünitesinde bebekleri bakım alan annelerin kaygı ve umutsuzluk düzeylerini etkileyen faktörlerin incelenmesi. Atatürk Üniversitesi Hemşirelik Yüksekokulu Dergisi. 2009; 12(4): 66-73.

30. Ichijima E, Kirk R, Hornblow A. Parenteral support in neonatal intensive care units: A cross-cultural comparison between New Zealand and Japan. Journal of Pediatric Nursing. 2011; 26(3): 206-15.

31. Kowalski WJ, Leef KH, Mackley A, Spear ML, Paul DA. Communicating with parents of premature infants: who is the informant?. Journal of Perinatology. 2006; 26(1): 44-8.

32. Abdeyazdan Z, Shahkolahi Z, Mehrabi T, Hajiheidari M. A family support intervention to reduce stress among parents of preterm infants in neonatal intensive care unit. Iran Journal Nurs Midwifery Res. 2014; 19(4): 349-53.

33. Boztepe H, Çavuşoğlu H. Bir üniversite hastanesindeki uygulamaların aile merkezli bakım yönünden incelenmesi. Sağlık Bilimleri Fakültesi Hemşirelik Dergisi. 2009; 16(1): 11-24.

34. Çekin B, Turan T. The stress levels of parents of premature infants and related factors in neonatal intensive care units. The Turkish Journal of Pediatrics. 2018; 60(2): 117-25.

35. Roque ATF, Lasiuk GC, Radünz V, Hegadoren K. A scoping review of the mental health of parents of infants in the NICU. Journal Obstetric Gynecol Neonatal Nurse. 2017; 46(4): 576-87.

36. Ding $\mathrm{X}$, Zhu L, Zhang R, Wang L, Wang T, Lotur JM. Effects of family-centred care interventions on preterm infants and parents in neonatal intensive care units: A systematic review and meta analysis of randomized controlled trials. Australian Critical Care. 2018; 32(1): 1-13.

37. Açıkgöz A, Ayvaz E. A Qualitative Study: Determination of the opinions and expectations of the families with infants treated at the newborn intensive care unit. Osmangazi T1p Dergisi. 2019; 41(3): 271-8.

38. Carter JD, Mulder RT, Bartram AF, Darlow BA. Infants in a neonatal intensive care unit: Parental response. Arch Dis Child Fetal Neonatal Ed. 2005; 90(2): 109-13. 